\title{
Simulation of soft and hard tissues and its effects on radiopacity of root canal sealers
}

\author{
Simulação de tecidos moles e duros e seus efeitos na \\ radopacidade de cimentos endodônticos
}

\section{Abstract}

Purpose: To simulate soft and hard tissues to assess radiopacity of three root canal sealers (Endofill, AH Plus and Sealer 26).

Methods: Five circular specimens $(10 \times 1 \mathrm{~mm})$ were made and three experimental conditions were created. Situation \# 1: an aluminum step wedge allowed specimen being submitted to three digital radiographs. Situation \#2: a retromolar mandibular segment containing the specimen was positioned between the digital sensor and X-ray machine. Situation \#3: a soft tissue simulating material (utility wax $-30 \mathrm{~mm}$ ) was associated with the mandibular segment. Mean gray values were measured using ImageTool 3.0 software. Two-way ANOVA and Tukey's test $(\alpha=0.05)$ was performed.

Results: Radiopacity increased when bone tissue was used $(P<0.05)$, except for $\mathrm{AH}$ Plus. Situation \#3 provided greater radiopacity $(P<0.05)$. Radiopacity between most and least sealers decreased $44 \%$ when Situation $\# 1$ and $\# 3$ were compared.

Conclusion: Simulated soft and hard tissues influenced the radiopacity of root canal sealers.

Key words: Radiopacity; soft and hard tissue; root canal sealers

\section{Resumo}

Objetivo: Simular tecidos moles e duros para avaliar a radiopacidade de três cimentos endodônticos.

Metodologia: Cinco espécimes circulares $(10 \times 1 \mathrm{~mm})$ foram confeccionados e três situações experimentais foram criadas. Situação \#1: espécime e uma escala de alumínio foram submetidos a 3 tomadas radiográficas digitais. Situação \#2: um segmento retromolar de uma mandibula humana contendo o espécime foi posicionada entre o aparelho de raio $X$ e o sensor digital. Situação \#3: um simulador de tecido mole (cera utilidade $-30 \mathrm{~mm}$ ) foi associado ao segmento mandibular. A média dos valores de cinza foi medida através do programa ImageTool 3.0. Análise de variância de dois critérios e Teste de Tukey $(\alpha=0.05)$ foram realizados para análise estatística.

Resultados: A radiopacidade aumentou quando tecido ósseo foi usado $(P<0.05)$, exceto para - Ah Plus. A Situação \#3 proporcionou os maiores valores de radiopacidade $(P<0.05)$. Os valores de radiopacidade entre o cimento mais e o menos radiopaco diminuiu $44 \%$ quando as situações \# 1 e \#3 foram comparadas.

Conclusão: A simulação de tecidos moles e duros influencia a radiopacidade de cimentos endodônticos.

Palavras-chave: Radiopacidade; tecidos moles e duros; cimentos endodônticos

\author{
Ricardo Abreu da Rosa a \\ Carlos Alexandre Souza Bier b \\ Charles Cunha Pereira ${ }^{c}$ \\ Marcus Vinícus Reis Só ${ }^{\circ}$ \\ Carlos Frederico Brilhante Wolle ${ }^{d}$
}

- School of Dentistry, Federal University of Rio Grande do Sul, Porto Alegre, RS, Brazil

${ }^{b}$ Division of Endodontics, Department of Stomatology, Federal University of Santa Maria, Santa Maria, RS, Brazil

c School of Dentistry, Brazilian Lutheran University (ULBRA), Cachoeira do Sul, RS, Brazil

d Division of Endodontics, Inga School (UNINGASM), Santa Maria, RS, Brazil

\author{
Correspondence: \\ Ricardo Abreu da Rosa \\ Faculdade de Odontologia - UFRGS \\ Rua Ramiro Barcelos, 2492 \\ Porto Alegre, RS - Brasil \\ 90035-003 \\ E-mail: rabreudarosa@yahoo.com.br
}

Received: August 9, 2011

Accepted: October 16, 2011

Conflict of Interests: The authors state that there are no financial and personal conflicts of interest that could have inappropriately influenced their work.

Copyright: (C) 2011 Rosa et al.; licensee EDIPUCRS This is an Open Access article distributed under the terms of the Creative Commons AttributionNoncommercial-No Derivative Works 3.0 Unported License. 


\section{Introduction}

Root canal sealers should present several physicochemical properties: biocompatibility, great sealing and easy handling, allow retreatment and have sufficient radiopacity to be distinguished from adjacent anatomical structures (1-3). Root canal sealer radiopacity has a particular importance for the evaluation of the quality of endodontic treatment, as well as being helpful in the assessment of possible voids in filling (4). According to the International Organization for Standardization ISO 6876 (2001)(5), root canal sealers should have a radiopacity of equivalent to not less than $3 \mathrm{~mm}$ of aluminum ( $\mathrm{mm} \mathrm{Al})(5)$.

In 1967, the radiopacity of endodontic sealers was investigated (6). Twelve years later, a comparison standard for radiopacity studies was developed. The optical radiographic densities of several impression materials were measured and the values expressed as an equivalent thickness of aluminum capable of producing a similar radiographic density (7). Beyer-Olsen \& Ørstavik (3) introduced a reproducible comparison standard using a 2-mm-increment aluminum step-wedge to determine the radiopacity of root canal sealers (3).

Recently, other studies have evaluated the radiopacity of root canal sealers (4,8-13). However, these studies did not consider the influence of soft and hard tissue on $\mathrm{X}$-ray dissipation. This phenomenon could affect the final radiopacity of root canal sealers (14). X-ray photons present low intensity when passing through an object, due to the atomic interactions that cause absorption and dissipation (14). It can be expected that this phenomenon also occurs when $\mathrm{X}$-rays are focused at the jaw, considering the presence of soft tissues and their influence on the final image. Kaffe \& Littner (15), using a phantom as soft tissue equivalent material, observed that the radiographic contrast between dentin and gutta-percha decreased 10\% when the initial and final images were compared. Souza et al. (16) analyzed the influence of wax, muscular tissue and fat soft tissues over the gray levels of the mandibular retromolar region, concluding that all tested materials influenced the gray levels.

Some materials have been studied as a substitute for soft tissue in laboratorial studies $(18,19)$. Water was the first soft tissue simulator (18). Bovine muscle was considered the gold standard for this purpose; however, other materials also were tested with similar results. According to Braga et al. (17), wax, self-cure acrylic resin and a combination of paraffin and wax all present similar optical densities when compared to a posterior mandibular cadaver segment.

Previous studies evaluating root canal sealers can overestimate the radiopacity of some sealers in vitro. However, when clinical conditions are simulated using bone tissue and soft tissue, the X-ray dissipation may influence the final images, reducing differences between the sealer radiopacities. The purpose of this present study was to analyze the influence of mandibular bone and mandibular bone plus simulated soft tissue in the radiopacity of three root canal sealers.

\section{Materials and Methods}

Three root canal sealers were used: AH Plus (Dentsply, Rio de Janeiro, Brazil), Sealer 26 (Dentsply, Rio de Janeiro, Brazil) and Endofill (Dentsply, Rio de Janeiro, Brazil). The materials were manipulated according to the manufacturers' instructions. Five specimens, measuring $10 \mathrm{~mm}$ in diameter and $1 \mathrm{~mm}$ thick, were fabricated from each material. Selfcure acrylic resin matrices were made and impressions were taken using a polyether impression material. Samples of the prepared sealers were inserted into the impressions and stored in a moist chamber (incubator) at $37^{\circ} \mathrm{C}$ until set.

The specimens were tested in three experimental situations:

Situation \#1: initially, an aluminum step wedge (from 2 to $16 \mathrm{~mm}$, in $2 \mathrm{~mm}$ increments) and specimens were separately positioned on digital sensors (Kodak RVG 6100; Eastman Kodak Co, Rochester, USA). Three radiographs were taken of each specimen using a Kodak 2100 (Eastman Kodak Co, Rochester, USA) intraoral x-ray unit, operating at $60 \mathrm{kV}, 7 \mathrm{~mA}$, and 0.32 seconds. The object-to-focus distance was $30 \mathrm{~cm}$.

Situation \#2: a retromolar mandibular segment was positioned between the digital sensor and X-ray machine. A notch sizing $10 \mathrm{~mm}$ in diameter and $2 \mathrm{~mm}$ thick, was made with a \#8 carbide bur (SS White, Rio de Janeiro, Brazil) in the medullar bone to insert and standardize the specimen placement. An aluminum step wedge was fixed on the mandibular bone using cyanoacrylate. The same radiographic protocol was performed as mentioned with Situation \#1.

Situation \#3: a utility wax (30 mm thickness) was positioned at the mandibular buccal aspect of the bone, covering the whole test region, to simulate soft tissue (17). The same radiographic protocol was performed as mentioned with Situation \#1 (Figure 1).

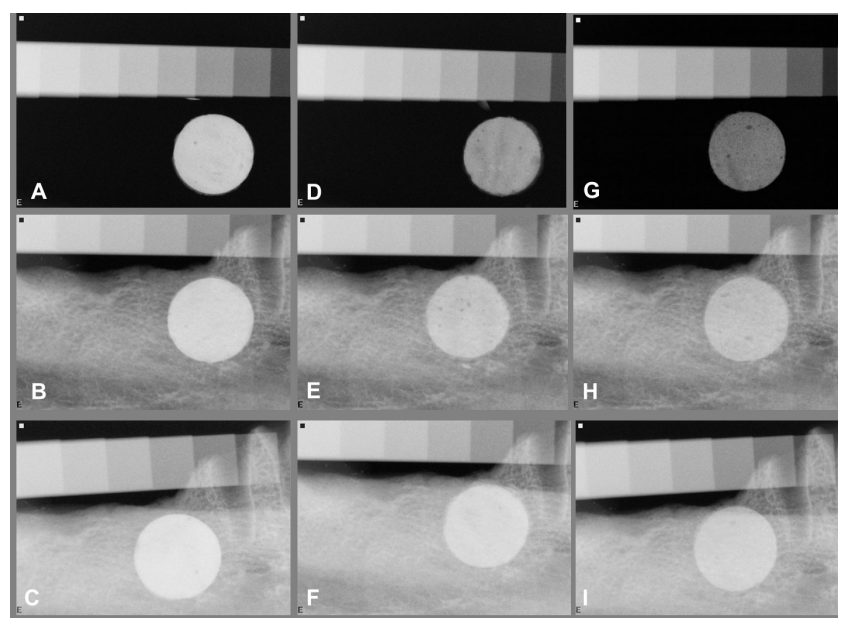

Fig. 1. Representative radiographs of the endodontic sealers according to the experimental situation. Each column represents a sealer, and each line represents an experimental situation: line 1 - absence of bone and simulated soft tissue; line 2 - presence of bone tissue; and line 3 - presences of bone and simulated soft tissue. AH Plus (A, B, C); Endofill (D, E, F); and Sealer $26(G, H, I)$. 
A blinded investigator measured the mean gray value of each aluminum step wedge and selected materials by outlining a region of interest by using the equal-density area tool of the ImageTool 3.0 (UTHSCSA, San Antonio, TX, USA). The regions were selected by avoiding areas containing air bubbles inside specimen. This procedure was repeated three times for each specimen and aluminum step wedge. Then, the average was calculated. The mean gray value of the material was converted into a millimeters of aluminum equivalent ( $\mathrm{mm} \mathrm{Al}$ ), permitting the comparison of the studied materials. Data were analyzed by using two-way ANOVA and Tukey's test $(\alpha=0.05)$.

\section{Results}

All of the tested materials showed radiopacity above $3 \mathrm{~mm}$ of aluminum, as recommended by ANSI/ADA Specification 57, regardless the absence or presence of mandibular bone singly or associated to simulated soft tissue. Figure 2 shows the radiopacity mean values and standard deviations of the investigated materials in each simulated situation. Radiopacity was expressed in equivalent millimeters of aluminum.

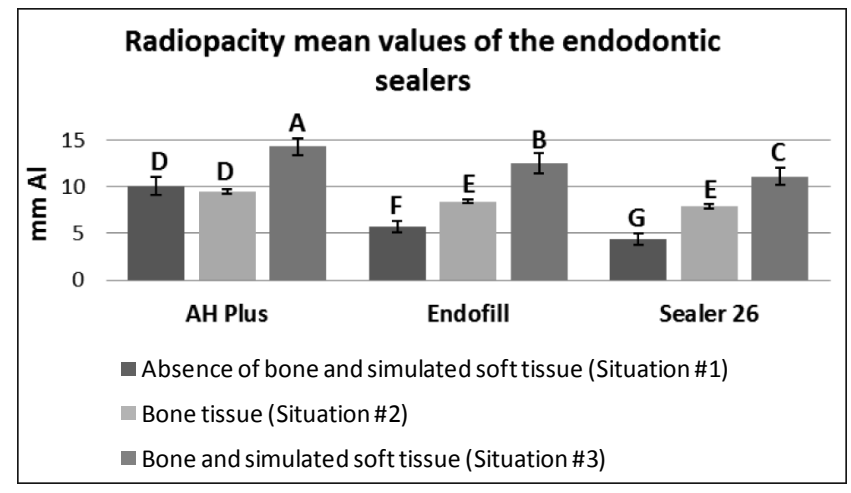

Fig. 2. Radiopacity mean values and SD of the endodontic sealers. Columns with the same capital letter were not significantly different $(P>0.05)$.

Statistically significant increase in radiopacity mean values occurred when bone tissue was used, except for $\mathrm{AH}$ Plus group. AH Plus presented radiopacity equivalent to 10.1 $\mathrm{mm} \mathrm{Al}$ in Situation \#1 and 9.5 mm Al in Situation \#2 $(P>0.05)$. Endofill and Sealer 26 presented $5.7 \mathrm{~mm} \mathrm{Al}$ and $4.4 \mathrm{~mm} \mathrm{Al}$ in Situation \#1 and $8.4 \mathrm{~mm} \mathrm{Al}$ and $7.9 \mathrm{~mm} \mathrm{Al}$ in Situation \#2, respectively $(p<0.05)$. When bone tissue and simulated soft tissue were used (Situation \#3) the radiopacity mean values were higher than the other experimental situations for all tested sealers $(p<0.05)$. Moreover, the difference between the most radiopaque and the least radiopaque sealers decreased for Situation \#1 when compared to Situation \#3. In Situation \#1 the difference of the radiopacity values between the most radiopaque (AH Plus, $10.1 \mathrm{~mm} \mathrm{Al}$ ) and de least radiopaque (Sealer 26, $4.4 \mathrm{~mm} \mathrm{Al}$ ) was $5.7 \mathrm{~mm} \mathrm{Al}$; however when bone tissue and simulated soft tissue were used, the difference between de most radiopaque (AH Plus, $14.3 \mathrm{~mm} \mathrm{Al}$ ) and the least radiopaque (Sealer 26, $11.1 \mathrm{~mm} \mathrm{Al}$ ) was $3.2 \mathrm{~mm} \mathrm{Al}$, it represents a $44 \%$ decrease.

\section{Discussion}

Several studies have evaluated the physical and chemical properties of dental materials. With regards to endodontic sealers, radiopacity should permit distinction between the materials and the surrounding anatomic structures $(3,19)$, to facilitate the evaluation of the quality of the root filling (20) and to allow for an adequate follow up (20).

One of the systems used to evaluate the radiopacity of dental materials is the digital X-ray $(21,22)$. This system does not need conventional periodical radiographic film or its chemical processing, thus saving time (23). Radiographic software allows for more detailed analysis of the digital image, which is shown on a computer screen and can be evaluated graphically or by the grey-pixel value (10). In addition, traditional film development, unless performed carefully, can produce significant variations in the final radiograph. Therefore, a digital method should provide more consistent results (22).

When evaluation was performed without the presence of bone or simulated soft tissue, values comparable with other reports $(9,10,13)$ were found in this present study. The three tested sealers presented results which were significantly different from each other $(P<0.05)$. AH Plus presented higher radiopacity mean values $(10.1 \mathrm{~mm} \mathrm{Al})$, followed by Endofill (5.7 $\mathrm{mm} \mathrm{Al})$ and Sealer 26 (4.4 $\mathrm{mm} \mathrm{Al})$. Tanomaru-Filho et al. (9) found similar values for Endofill and Sealer 26, but higher values for AH Plus. Carvalho Jr, et al. (10) also observed similar values for the same materials. Previous studies have indicated that AH Plus was more radiopaque than Endofill, which was more radiopaque than Sealer 26 (9,10,11-13). An analysis of the formulations of the sealers showed that they have radiopacifier agents. AH Plus, a two component paste root canal sealer based on a polymerization reaction of epoxy resin-amines (24), contains zirconium oxide which contributes to a greater radiopacity in relation to the other tested sealers (8). Endofill is a zinc oxide-eugenol-based sealer; it has barium sulphate, zinc oxide and bismuth subcarbonate as radiopacifiers (25). Sealer 26 contains bismuth oxide, acting as the radiopacifier (8). These radiopacifiers could explain the high difference in radiopacity mean values between these sealers when exposed directly to X-rays.

In Situation \#2, using a retromolar mandibular segment, the radiopacity mean values became higher for Endofill and Sealer $26(P<0.05)$ when compared to themselves in Situation \#1. Endofill presented $47 \%$ increase in radiopacity mean values (in Situation \#1 presented $5.7 \mathrm{~mm} \mathrm{Al}$ and in Situation \#2, $8.4 \mathrm{~mm} \mathrm{Al}$ ). Sealer 26, in turn, presented $4.4 \mathrm{~mm}$ $\mathrm{Al}$ in Situation \#1 and $7.9 \mathrm{~mm} \mathrm{Al}$ when bone tissue was used. It represents a $79 \%$ increase in radiopacity mean values for Sealer 26. However, AH Plus presented similar values in both experimental situations $(P>0.05)$ 
In order to simulate soft tissue, $30 \mathrm{~mm}$-thick utility wax was used at the buccal aspect of the bone specimen (17). Other materials could be used for this purpose, like paraffin, self-cure acrylic resin and a mixture of paraffin and wax with the same influence over the optical density of the final radiographic image (17). However, utility wax was the chosen material due its easy handling. Another study (15) used phantom to simulate soft tissues. However, the content within the phantom was not described, making it difficult to be reproduced.

Overlapping bone, soft tissue and the specimen (Situation $\# 3)$, radiopacity increased significantly in comparison with Situation \#1 and \#2 $(P<0.05)$. When compared to itself in Situation \#1, AH Plus presented a $41 \%$ increase in its radiopacity (10.1 mm Al to $14.3 \mathrm{~mm} \mathrm{Al})$; Endofill presented a $119 \%$ increase $(5.7 \mathrm{~mm} \mathrm{Al}$ to $12.5 \mathrm{~mm} \mathrm{Al})$ and Sealer 26 , $152 \%$ (4.4 mm Al to $11.1 \mathrm{~mm} \mathrm{Al})$. The difference between the most and the least radiopaque sealers in Situation \#1 was $5.7 \mathrm{~mm}$ Al. When Situation \#3 was analyzed, the difference decreases to $3.2 \mathrm{~mm} \mathrm{Al}$. This reduction, although representing a $44 \%$ decrease, was not enough to turn the sealers statistically similar. However, it seems clear that when bone tissue and utility wax are used the difference in radiopacity between the tested sealers decreases. This phenomenon occurs due to $\mathrm{X}$-ray dissipation (14). Atomic interactions cause absorption and dissipation of the X-ray photons when they pass through an object. Therefore, X-rays present lower intensities when passing through thicker materials (14).

Several studies that have analyzed root canal sealer radiopacity, but that did not consider the alteration caused by hard and soft tissues, may overestimate sealers with high radiopacity values and underestimate sealers with worse results (4,8-13). The current findings show the importance of approximating the clinical conditions. Thus, studies that evaluate root canal sealer radiopacity must take into account the influence of soft and hard tissues on the of endodontic sealers radiopacity.

\section{Conclusion}

Bone tissue (except for AH Plus) and association between bone and simulated soft tissue increased the radiopacity of the root canal sealers and decreased the difference between their radiopacity when compared with direct exposure to X-ray.

\section{Acknowledgements}

The authors thank Federal University of Santa Maria (UFSM) and the UFSM Health Center of Science. phosphate and other root-end filling materials. Int Endod J 2000;33:31 1-5.

2. McComb D, Smith DC. Comparison of physical properties of polycarboxylate-based and conventional root canal sealers. J Endod 1976;2:228-35.

3. Beyer-Olsen EM, Orstavik D. Radiopacity of root canal sealers. Oral Surg Oral Med Oral Pathol 1981;51:320-8

4. Baksi Akdeniz BG, Eyüboglu TF, Sen BH, Erdilek N. The effect of three different sealers on the radiopacity of root fillings in simulated canals. Oral Surg Oral Med Oral Pathol Oral Radiol Endod 2007;103:138-41.

5. International Organization for Standardization (ISO) 6876:2001, Geneva, Switzerland. Dental Root canal Sealing Materials.

6. Higginbotham TL. A comparative study of physical properties of five commonly used root canal sealers. Oral Surg Oral Med Oral Pathol 1967;24:89-101.

7. Eliasson ST, Haasken B. Radiopacity of impression materials. Oral Surg Oral Med Oral Pathol 1979;47:485-91.

8. Tanomaru JMG, Cezare L, Gonçalves M, Tanomaru Filho M. Evaluation of the radiopacity of root canal sealers by digitization of radiographic images. J Appl Oral Sci 2004; 12:355-7.

9. Tanomaru-Filho M, Jorge EG, Guerreiro Tanomaru JM, Gonçalves M. Radiopacity evaluation of new root canal filling materials by digitalization of images. J Endod 2007;33:249-5.

10. Carvalho-Junior JR, Correr-Sobrinho L, Correr AB, Sinhoreti MA, Consani S, SousaNeto MD. Radiopacity of root filling materials using digital radiography. Int Endod J 2007;40:514-20.

11. Tanomaru-Filho M, Jorge EG, Tanomaru JM, Gonçalves M. Evaluation of the radiopacity of calcium hydroxide and glass-ionomer-based root canal sealers. Int Endod J 2008;41:50-3.

12. Tanomaru-Filho M, da Silva GF, Duarte MA, Gonçalves M, Tanomaru JM Radiopacity evaluation of root-end filling by digitalization of images. J Appl Oral Sci 2008; 16:376-9

13. Taşdemir T, Yesilyurt C, Yildirim T, Er K. Evaluation of the radiopacity of new root canal paste/sealers by digital radiography. J Endod 2008;34:1388-90.

14. Pietrobelli A, Formica C, Wang Z, Heymsfield SB. Dual-energy x-ray absorptiometry body composition model: review of physical concepts. Am J Physiol 1996;271:e941-51. 
15. Kaffe I, Littner MM. Influence of soft tissue on dentistry and relative contrast between gutta percha and dentin images. Dentomaxillofac Radiol 1995;24:46-9.

16. Souza PH, da Costa NP, Veeck EB. Influence of soft tissues on mandibular Gray scale levels. Braz Oral Res 2004;18:40-4.

17. Braga CMP, Gegler A, Fontanella V. Evaluation of the influence of the thickness and of the relative position of soft tissues simulating materials in the optic density of periapical radiographies of the posterior region of the mandibule. Braz Dent Sci 2006;9:52-8.

18. Cook JE, Cunningham JL. The assessment of fracture healing using dual x-ray absorptiometry: a feasibility study using phantons. Phys Med Biol 1995;40:1 19-36.

19. Katz A, Kaffe I, Littner M, Tagger M, Tamse A. Densitometric measurement of radiopacity of Gutta-percha cones and root dentin. J Endod 1990;16:211-3.

20. Goldman M, Simmonds S, Rush R. The usefulness of dye-penetration studies rexamined. Oral Surg Oral Med Oral Pathol 1989;67:327-32.

21. Sabbagh J, Vreven J, Leloup G. Radiopacity of resin-based materials measured in film radiographs and storage phosphor plate (Digora). Oper Dent 2004;29:677-84.

22. Gu S, Rasimick BJ, Deutsch AS, Musikant BL. Radiopacity of dental materials using adigital X-ray system. Dent Mater 2006;22:765-70.

23. McDonnell D, Price C. An evaluation of the Sens-A-Ray digital dental imaging system. Dentomaxillofac Radiol 1993;22:121-6.

24. Cohen BI, Pagnillo MK, Musikant BL, Deutsch AS. An in vitro study of the cytotoxicity of two root canal sealers. J Endod 2000;26:228-9.

25. Kopper PM, Figueiredo JA, Della Bona A, Vanni JR, Bier CA, Bopp S. Comparative in vivo analysis of the sealing ability of three endodontic sealers in post-prepared root canals. Int Endod J 2003;36:857-63. 